
and Shixiang Li

\title{
A new method of lithologic identification and distribution characteristics of fine - grained sediments: A case study in southwest of Ordos Basin, China
}

https://doi.org/10.1515/geo-2019-0002

Received May 17, 2018; accepted October 11, 2018

Abstract: Lithologic identification is critical for studying fine - grained sediments, which further elucidates sedimentary environment, and formation. The oil - bearing Chang 7 Section of the Yanchang Formation in Ordos Basin contains thick dark mudstone with a wide distribution, interbedded by siltstone and fine sandstone. The lacustrine fine - grained sedimentary rocks constitute the chief source rock of the Yanchang Formation. On the grounds of fine core description, thin rock slice identification and $\mathrm{X}$ ray diffraction analysis, we proposed a new method based on conventional logging data. This method is using density (DEN) and natural gamma (GR) logging curve intersection and multivariate linear regression analysis of logging curve value and measured mineral content value which is carried out by SPSS software to identify the lithology and the vertical distribution characteristics of fine - grained sedimentary rock of Chang 7 formation in the study area. This method is mainly suitable for lithologic identification of fine - grained sedimentary rocks in lake basin. It not only quantitatively analyses the contents of main minerals and organic matter in fine - grained sedimentary rocks, but also greatly improved the accuracy and universality of using conventional logging data to identify the lithology of fine grained sedimentary rocks, which provides a reference for the exploration of tight oil.

Keywords: lithologic identification, fine - grained sediments, multiple linear regression analysis, Ordos Basin, the oil - bearing Chang 7 Section

\footnotetext{
*Corresponding Author: Qiqi Lyu: Hubei Cooperative Innovation Center of Unconventional Oil and Gas (Yangtze University), Wuhan, Hubei, 430100, China; Laboratory of Exploration Technologies for Oil and Gas Resources (Yangtze University), Ministry of Education, Wuhan, Hubei, 430100, China; Email: 569274193@qq.com
}

\section{Introduction}

Tight oil (shale oil) and gas exploration via the analysis of fine - grained sediments has attracted attention globally [1-3]. Based on the modern marine survey and typical outcrop anatomy, the formation of marine fine - grained sediments has been systematically studied abroad, and the genetic mechanism meanwhile distribution pattern of marine siltstone and organic - rich shale were basically defined. In recent years, Chinese scholars have fully drew lessons from the research experience of fine - grained sedimentary rocks abroad [4-6], using scanning electron microscopy and automated mineral analysis (QEMSCAN), X - ray diffraction (XRD), pressure pulse attenuation, and nuclear magnetic resonance and elemental capture spectroscopy (ECS) logging. The abovementioned

Shunshe Luo: Hubei Cooperative Innovation Center of Unconventional Oil and Gas (Yangtze University), Wuhan, Hubei, 430100, China

Yulong Guan: Laboratory of Exploration Technologies for Oil and Gas Resources (Yangtze University), Ministry of Education, Wuhan, Hubei, 430100, China

Jinhua Fu: National Engineering Laboratory for Exploration and Development of Low-Permeability Oil \& Gas Fields, Xi'an, Shaanxi, 710018, China; PetroChina Changqing Oilfield Company, Xi'an, Shaanxi, 710018, China

Xiaobing Niu: Research Institute of Exploration and Development, PetroChina Changqing Oilfield Company, Xi'an, Shaanxi, 710018, China

Liming Xu: Research Institute of Exploration and Development, PetroChina Changqing Oilfield Company, Xi'an, Shaanxi, 710018, China

Shengbin Feng: Research Institute of Exploration and Development, PetroChina Changqing Oilfield Company, Xi'an, Shaanxi, 710018, China

Shixiang Li: Research Institute of Exploration and Development, PetroChina Changqing Oilfield Company, Xi’an, Shaanxi, 710018, China 
methods have improved our understanding of the petrological properties [7-13], sedimentary environment [1417], reservoir properties [18-22], source rock characteristics [23, 24], distribution [14, 25], and formation of finegrained sedimentary rocks $[11,14,26]$. The identification of the lithologies of fine - grained sedimentary rocks helps constrain the sedimentary environment, distribution characteristics, and formation. It also helps to establish reservoir fluid - flow models, which is of significance to predicting production performance, well deployment, well pattern optimization, and economic evaluation of tight oil and gas [27-30].

Presently, lithologic identification methods include the description of core data and outcrops, thin section and X - ray diffraction data, automated mineral analysis (QEMSCAN), conventional logging, gravity and magnetic surveys, seismic exploration, well logging, remote sensing, etc. (Table 1) [31]. Among them, lithology identification from logging data has high detection depth and vertical resolution, which is the most commonly used lithology identification method in oil and gas exploration. Conventional logging-based lithology identification includes intersection plots, curve overlapping, discriminant analysis, fuzzy clustering, artificial neural networks, etc. [32-34]. These methods have their advantages and limitations [35], however, they are primarily applicable to coarse-grained deposits, the identification of lacustrine fine - grained sediments often relies on special logging methods such as ECS or CMR to improve the accuracy of interpretation. However, the cost of these special logging methods is high and old wells generally do not have the appropriate equipment installed; thus, these methods are not common (Table 2) $[36,37]$. On the base of fine - grained core descriptions, thin section identification, and XRD analysis of the oil - bearing Chang 7 Section of the Yanchang Formation in the southwest of Ordos Basin, a new method to identify the lithology is proposed which is based on conventional logging data and the correlation of various logging parameters and mineral content. We use this method to study the characteristics of lithologic identification and fine - grained sedimentary distribution characteristics of Chang 7 oil - bearing formation, and provide reference for the exploration of tight oil in fine - grained sedimentary area.

\section{Geological background}

The Ordos Basin in the western part of the North China platform is a large - scale cratonic depression covering the
Palaeozoic, Mesozoic, and Cenozoic basins (Figure 1) [38]. Based on the sequence of the lacustrine sediments and the vertical distribution of oil-bearing layers, the Yanchang Formation of Upper Triassic is divided into five lithologic sections and ten oil - bearing sections (Chang 10 Chang 1). The Chang 7 Section represents a major stage in the development of the lake basin in the Yanchang Period. The center of the lake basin is located in Longdong, an area southwest of the Ordos basin. Thick dark mudstone (oil shale), interbedded with thin - middle layer siltstone and fine - grained sandstone (100 - $120 \mathrm{~m}$ thick), are commonly found here. The sediments at the lake margins are represented by deltaic sand deposits. The sedimentary facies change regularly from the edge of the lake basin to its center. The northeastern part of the lake basin develops meandering river delta plane and front deposits, whereas the southwest part of the lake basin is characterized by braided river delta front deposits. The delta plane subfacies are fine sandstones, whereas the delta front subfacies are mainly siltstones. The central lacustrine is the main source rocks depositing area, in where the subfacies are semi - deep - to - deep lake deposit, and the deposits are shale and oil shale. The transitional zone comprises distal delta front and deepwater gravity flow deposits.

The oil - bearing Chang 7 Section is divided into Chang $7_{3}$, Chang $7_{2}$, and Chang $7_{1}$ from bottom to top. Chang $7_{3}$ represents the longest lacustrine transgression period in the Mesozoic in the basin. The deep lake area is vast and is represented by high - quality dark mudstones and black organic - rich shale. In Chang $7_{2}$ sedimentary period, the lake area had gradually decreased. The delta sand deposits in the northeastern and southwestern regions advanced to the semi - deep and deep lake areas. Amounts of sediments from the southwest and south deposits on delta front and shallow lacustrine, and gravity flow deposits developed in the distal of the delta front and semi - deep lake areas. In Chang $7_{1}$, the subsidence of the lake basin appears to have slowed, the lake basin area has contracted, the deposition exceeded the sedimentation rate, and the deposition of delta front deposits owing to high - energy traction currents increased. During this period, delta front sand deposits and gravity flow deposits from different sources accumulated in the center of the lake basin, producing fine - grained sheet - like sand bodies with wide distribution. These fine - grained clastic rocks fully covered the high organic shale, forming a unique "broad sedimentation" configuration combination of source and reservoir in the Mesozoic. 
Table 1: Lithological identification

\begin{tabular}{|c|c|c|}
\hline Method & Advantages & Disadvantages \\
\hline Gravity and magnetic surveys & $\begin{array}{l}\text { Wide area coverage; high } \\
\text { sampling density; three - } \\
\text { dimensional inversion } \\
\text { algorithms are mature; easy to } \\
\text { obtain a large range of } \\
\text { lithologies }\end{array}$ & $\begin{array}{l}\text { Poor vertical resolution and } \\
\text { strong multiple solutions }\end{array}$ \\
\hline Seismic surveys & $\begin{array}{l}\text { Large depth range and high } \\
\text { precision }\end{array}$ & High cost \\
\hline Well logging & $\begin{array}{l}\text { High precision; mature } \\
\text { technology; numerous } \\
\text { methods and algorithms }\end{array}$ & $\begin{array}{c}\text { Only a small area near the } \\
\text { borehole is used; difficult to } \\
\text { identify lithologies in areas } \\
\text { without boreholes }\end{array}$ \\
\hline Remote sensing & $\begin{array}{c}\text { Fast data - update speed and } \\
\text { large area coverage }\end{array}$ & $\begin{array}{l}\text { Small detection depth; } \\
\text { affected by vegetation } \\
\text { coverage }\end{array}$ \\
\hline
\end{tabular}

Table 2: Logging lithologic identification

\begin{tabular}{|c|c|c|}
\hline Method & Advantages & Disadvantages \\
\hline Cross plotting & $\begin{array}{l}\text { Less use of parameters, } \\
\text { identification is relatively } \\
\text { simple and convenient }\end{array}$ & $\begin{array}{c}\text { Lithology identification results } \\
\text { may be of poor equality }\end{array}$ \\
\hline Curve overlapping & Simplicity & $\begin{array}{l}\text { Only applies to simple } \\
\text { lithologies }\end{array}$ \\
\hline Discriminant analysis & $\begin{array}{l}\text { Identification of complex } \\
\text { lithologies; high adaptability } \\
\text { and recognition accuracy }\end{array}$ & $\begin{array}{c}\text { High data volumes are needed; } \\
\text { the lithology indicators must } \\
\text { be comprehensive }\end{array}$ \\
\hline Fuzzy clustering & $\begin{array}{l}\text { Identification of thin interbed } \\
\text { layers and interlayer divisions; } \\
\text { high resolution }\end{array}$ & $\begin{array}{l}\text { Complex operation; } \\
\text { performance is guaranteed if } \\
\text { the training sample is infinite }\end{array}$ \\
\hline Artificial neural networks & $\begin{array}{c}\text { All kinds of logging data are } \\
\text { used }\end{array}$ & $\begin{array}{c}\text { Complex operation; } \\
\text { completeness of samples, } \\
\text { patterns, and data and errors } \\
\text { need to be reconsidered }\end{array}$ \\
\hline ECS and CMR logging & $\begin{array}{l}\text { High precision; suitable for } \\
\text { lacustrine fine - grained } \\
\text { sediments. }\end{array}$ & High cost \\
\hline
\end{tabular}

\section{Lithologic features of the fine - grained sediments}

The term fine - grained sedimentary rock refers to the content of grain whose diameter less than $0.0625 \mathrm{~mm}$ is more than $50 \%$, and is mainly composed of clay, siltstone, and small amounts of endogenic carbonates, biological silica minerals, phosphates [39, 40].

Fine - grained sedimentary rocks is too fine to identify the mineral content by thin sections only. XRD can yield the mineral composition of samples based on the characteristic diffraction peaks of different minerals and the relationship between the mineral content and the intensity of 


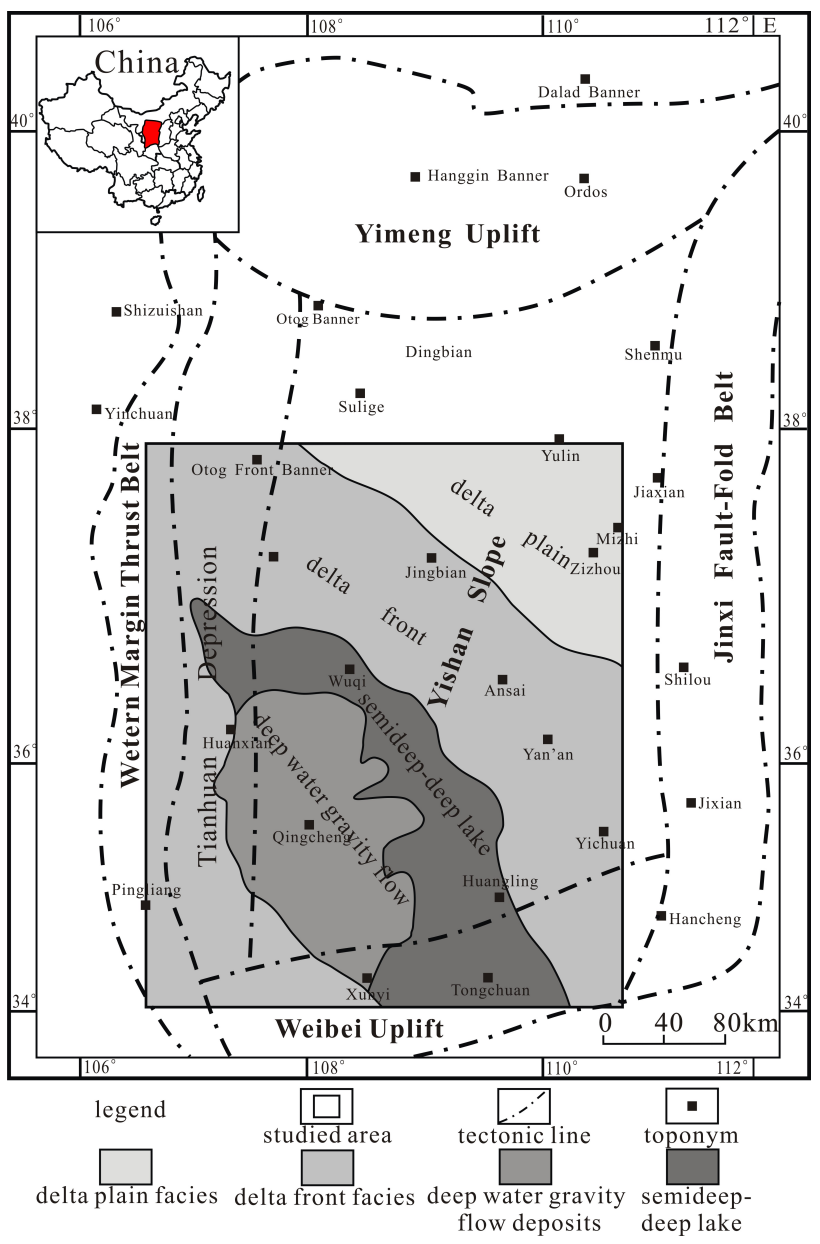

Figure 1: Tectonic map and sedimentary facies in the study area.

its diffraction peaks. Thus we combine thin sections and XRD to identify the minerals and mineral content of fine grained sedimentary rocks in the study area. The thin sections were analyzed at the Key Laboratory of Oil \& Gas Resources and Exploration Technologies, Ministry of Education (Yangtze University), using a Carl Zeiss petrographic microscope (AxioScope.A1) with an ICCS optical system and magnification of $40 \times$ to $1000 \times$. The XRD data were collected at the Materials and Chemical Analysis and Testing Center in China University of Geosciences (Wuhan). A D8-FOCUS diffractometer with $\mathrm{CuK} \alpha$ radiation and $\mathrm{Ni}$ filter was used with the experimental conditions of $40 \mathrm{kV}$ and $40 \mathrm{~mA}$, along with a LynxEye192 bit array detector with a $2 \theta$ scanning step of $0.01^{\circ}, 2 \theta$ range of $5-60^{\circ}$, scanning speed $0.05 \mathrm{~s} /$ step, and $\lambda=1.540598 \mathrm{~A}$.

The fine - grained sediments of oil - bearing Chang 7 comprise mudstone, shale, siltstone, a small amount of carbonates and intermediate types of rock, which mainly deposit in delta front, semi - deep, and deep lacustrine deposits. Based on $141 \mathrm{XRD}$ patterns from Chang 7, the mineral content was observed as follows: quartz 31.7\%, feldspar $38.1 \%$, clay minerals $24.2 \%$, calcite and dolomite $4.0 \%$, laumontite and clinoptilolite $0.8 \%$, and pyrite $1.2 \%$. Despite the differences in the minerals from the different sedimentary environments, the intermediate rocks are dominated by quartz and feldspar.

\section{Lithologic identification of fine - grained sediments}

\subsection{Identification principles}

The mineral composition and content of different fine grained sedimentary rocks vary. Different minerals have different resistivities (RT), natural gamma rays (GR), acoustic (AC) velocities, densities (DEN), and neutron (CNL) absorption characteristics. Therefore, the logging responses of shale, sandstone, and carbonates vary regularly at the macroscale level (Table 3).

RT and GR are common in lithologic identification applications, and have achieved good application. AC, DEN and CNL are commonly used to calculate the porosity of coarse grained sandstone, their logging responses reflect the integrated information of the lithology, petrophysical properties and fluid properties. When one kind of information is weakened or reduced, the others will be highlighted. Due to the small porosity of fine - grained sedimentary rocks, siltstone is generally less than $10 \%$ and the porosity of shale is generally less than $6 \%$, so the response of AC, DEN and CNL to physical properties is relatively weak. The logging response characteristics of the oil and gas section are characterized by increase of $\mathrm{AC}$, reduction of DEN, and increase of CNL. The obvious hydrocarbon bearing reservoir has correspondingly obvious responses, therefore, it is not necessary to suppress oil and gas information reflected by the AC, DEN and CNL methods at present. On the contrary, if the series of logging reactions are insensitive, it can not reflect the oil - bearing property of the section, resistivity or nuclear magnetic resonance and geologic logging data can be used jointly to find out the influence of oil and gas on AC, DEN and CNL, and combined with the lithology information of weak hydrocarbon - bearing zone, the lithology can be analyzed from multi well correlation. Therefore, AC, DEN and CNL can also be used for lithologic identification of fine-grained sedimentary rocks (Figure 2). 
Table 3: Logging responses vs lithology

\begin{tabular}{cccccc}
\hline Lithology & $\mathrm{GR}(\mathrm{API})$ & $\begin{array}{c}\mathrm{DEN} \\
\left(\mathrm{g} / \mathrm{cm}^{3}\right)\end{array}$ & $\Delta \mathrm{t}\left(\mu \mathrm{s} \cdot \mathrm{m}^{-1}\right)$ & $\rho\left(\mathrm{g} \cdot \mathrm{cm}^{-3}\right)$ & $\Phi_{N}(\%)$ \\
\hline Shale & $>110$ & $2.20-2.55$ & $>300$ & $2.10-2.50$ & $30-40$ \\
Sandstone & $40-110$ & $2.40-2.60$ & $180-250$ & $2.30-2.65$ & $10-23$ \\
Limestone & $20-60$ & $2.70-2.90$ & $165-250$ & $2.40-2.70$ & $0-3$ \\
Dolomite & $60-90$ & $2.68-2.85$ & $155-250$ & $2.50-2.85$ & $2-21$ \\
\hline
\end{tabular}

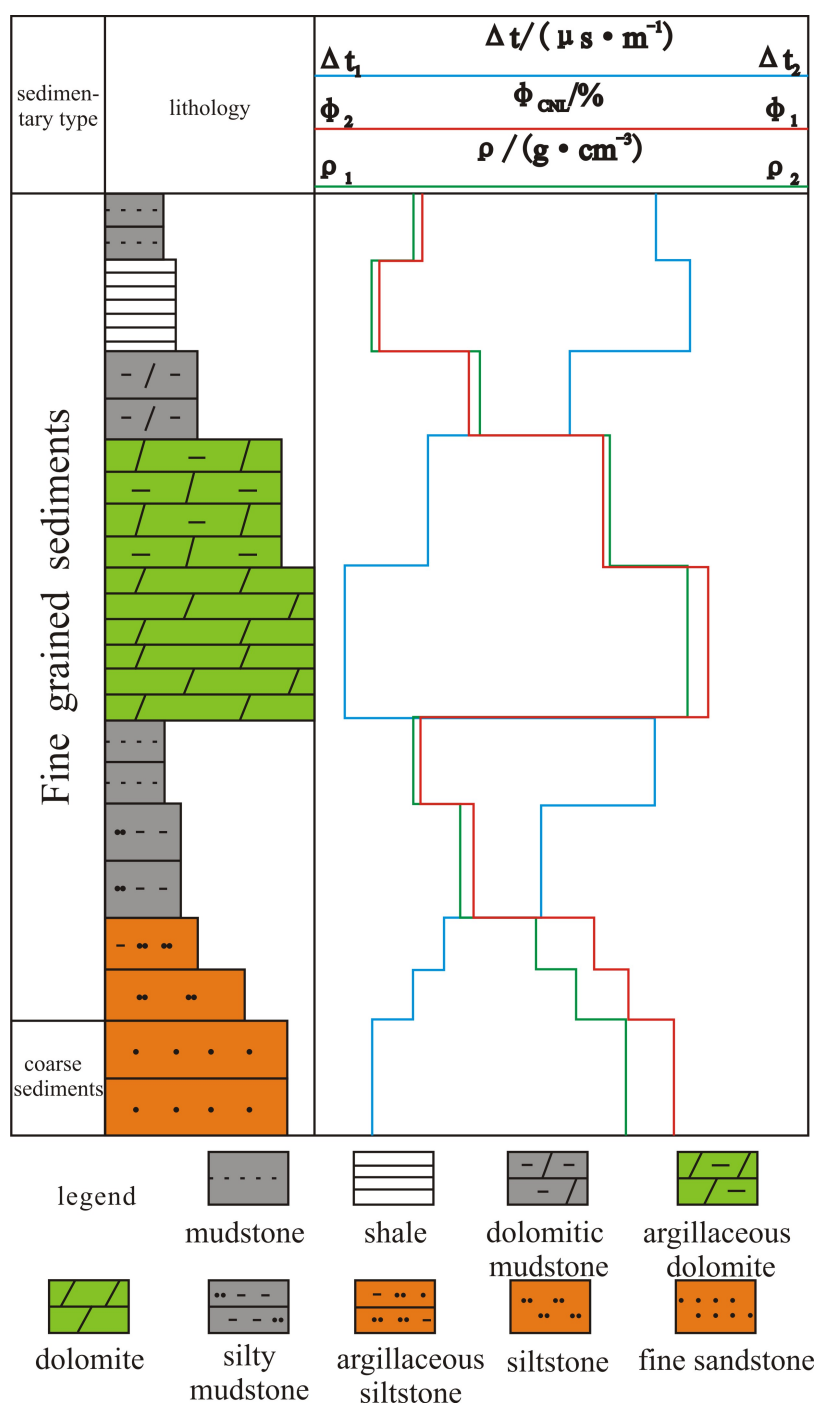

Figure 2: Typical logging data vs lithology.

\subsection{Identification method}

The following steps are used to identify the lithology of the fine - grained sediments in the study area.

First, core logging is performed at each coring well to ensure one - to - one correspondence of data. Second, Under the constraints of thin section identification and the measured data of XRD, a rock - electricity response chart of varies logging data and lithologies is set up by using logging curve cross plotting. Then a large number of data analysis and verification are used to observe its significance, and select the logging parameter variables with significant level. By using logging curve cross plotting of DEN and GR to preliminary identify the main types of fine - grained sedimentary rocks in different depositional system environments. Third, we perform multiple linear regression of mineral content and logging data versus well depth to observe the significance of the regression and coefficient, to eliminate the insignificant variables, and to fit the relation between the mineral content and the well measured value, i.e., the calculated mineral content. Fourth, we estimate the main minerals of the fine - grained sedimentary rocks and compare the calculated mineral content to that derived from the XRD patterns. If the test results are highly accurate, the recognition method can be used to explain the sedimentary lithology of fine - grained sediments in the oil - bearing Chang 7 Section.

(1) Preliminary calibration of fine - grained sedimentary rocks

The oil - bearing Chang 7 Section mainly comprises fine - grained sedimentary rocks such as siltstone, dark mudstone and black shale, and fine sandstone. First, on the basis of fine observation and description of cores, the logging is homing of each coring well. Based on thin section and XRD data, the rock - electricity response chart of varies logging data and lithologies is set up. A large number of data analysis and verification have been made, and we find that the changes of GR and DEN have a good correlation with the changes of lithology. Subsequently, GR and DEN are selected to predict the fine sedimentary rock types in the study area. The logging curve crossplot method (Figure 3) is established for the fine-grained sedimentary rocks of different sedimentary facies with the braided river delta, meandering river delta, and the semi - deep - to - deep lake deposit. The semi - deep - to - deep lake sedimentary sand body is mainly caused by the gravity flow. Therefore, the conventional GR and DEN logging curve parameters can be used to preliminarily calibrate the types of fine - grained sedimentary rocks. 

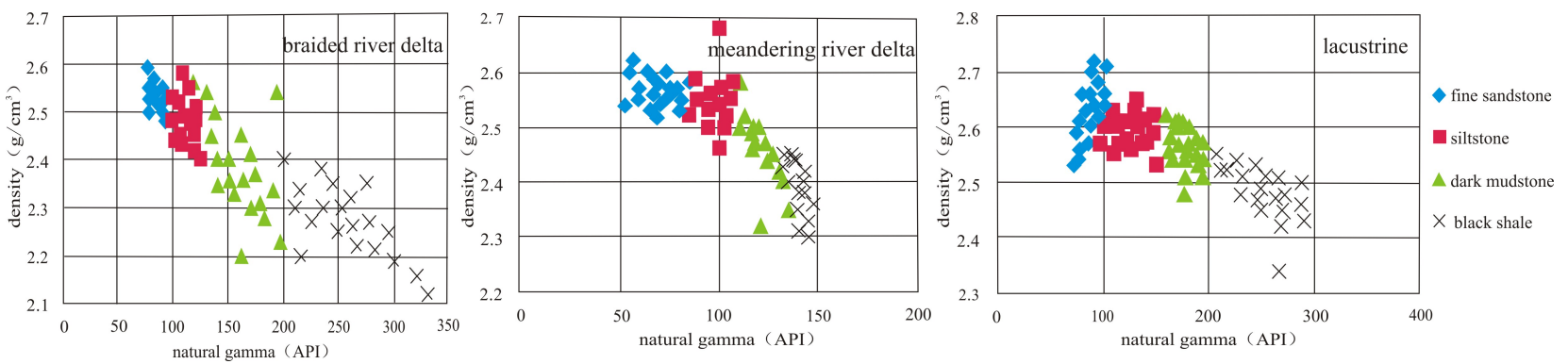

Figure 3: Correlations of logging parameters in the Chang 7 fine - grained sediments.

By statistic the GR and DEN values of fine-grain sedimentary rocks in different sedimentary environments, we find that in different sedimentary environments even the same type of fine-grained sedimentary rocks have different GR and DEN value, as shown in Table 4.

(2) Calibration of mineral content

Using the logging curve crossplot, the main finegrained sedimentary rocks in the study area can be preliminarily calibrated to identify different rocks in sedimentary system environment; however, the main mineral content of the fine-grained sedimentary rocks cannot be predicted. Further, it is very hard to determine the mineral content of the all core by via XRD, and the core in one well is limited. In order to understand the distribution of main mineral content in the entire well section, we use point segment modeling method to obtain the various conventional logging value in the depth that XRD samples corresponded. It means the conventional logging parameters value is the average value $10 \mathrm{~cm}$ up and down at the depth the XRD samples corresponded, which effectively avoids the relative error caused by the depth homing deviation of cores. We use the conventional logging data as a variable and the SPSS software to perform multiple linear regression analysis on the measured data of the mineral content to observe the significance of the regression equation and coefficient and to eliminate the parameter variables that fail to reach the corresponding significant level. Further, the calculation formula of the main mineral content is fitted to obtain the distribution curves of major mineral contents in the whole well section. Next, we derive the relation between mineral and total organic carbon content and RT, GR, AC, DEN, and CNL in the oil - bearing Chang 7 Section (Table 5). The deviations between predicted and observed mineral content are shown in Figure 4.

(3) Nomenclature of fine - grained sedimentary rocks

Based on the above methods, lithologic identification was performed on the fine - grained sediments of oil bearing Chang 7 Section. To accurately predict the various conventional logging curves of fine sedimentary rocks corresponding to the depth of the well, the primary fine - grained sedimentary rocks in the study area are preliminarily calibrated using DEN and GR logging data. Then, using the prediction formula of the main minerals, mineral content in the fine - grained sedimentary rocks was calculated. Subsequently, the fine - grained sedimentary rocks are named by color, single - layer thickness, texture and structure, organic matter content and mineral composition. Through large analysis, the fine - grained sedimentary rocks mainly developed in the Chang 7 oil - bearing formation show in Table 6.

\subsection{Discussion}

The C96 well in Chang 7 yielded high - quality logging and XRD data and was thus selected to discuss the vertical distribution of the lithologies; the data was also verified by combining core and thin sections. We performed statistical analysis of the mineral and organic matter data using the SPSS software (Table 5); the main mineral content and the organic carbon prediction formula were fitted to the 22 data points in well C96. Then, we compared the deviation between predicted and measured data. The relative deviation (RD) for quartz is $9.460 \%$, for feldspar is $8.820 \%$, for illite is $10.038 \%$, for chlorite is $9.959 \%$, and TOC is $10.719 \%$ (Table 7), indicating that the prediction model (Table 5) yielded accurate results. Therefore, the SPSS software can be used to fit the main mineral content and the organic carbon prediction formula method to identify the lithologies of fine - grained sedimentary rocks and further explore the distribution characteristics of fine - grained sedimentary rocks. 
Table 4: Logging parameters vs lithology in the Chang 7 oil - bearing Section

\begin{tabular}{|c|c|c|c|c|c|c|c|c|c|c|c|c|}
\hline \multirow[t]{2}{*}{ Parameter } & \multicolumn{4}{|c|}{ Braided river delta } & \multicolumn{4}{|c|}{ Meandering river delta } & \multicolumn{4}{|c|}{$\begin{array}{c}\text { Semi - deep - deep lacustrine } \\
\text { deposits (including gravity } \\
\text { flows) }\end{array}$} \\
\hline & $\begin{array}{l}\text { fine } \\
\text { sand- } \\
\text { stone }\end{array}$ & siltstone & $\begin{array}{l}\text { dark } \\
\text { mud- } \\
\text { stone }\end{array}$ & $\begin{array}{l}\text { black } \\
\text { shale }\end{array}$ & $\begin{array}{l}\text { fine } \\
\text { sand- } \\
\text { stone }\end{array}$ & siltstone & $\begin{array}{l}\text { dark } \\
\text { mud- } \\
\text { stone }\end{array}$ & $\begin{array}{l}\text { black } \\
\text { shale }\end{array}$ & $\begin{array}{l}\text { fine } \\
\text { sand- } \\
\text { stone }\end{array}$ & siltstone & $\begin{array}{l}\text { dark } \\
\text { mud- } \\
\text { stone }\end{array}$ & $\begin{array}{l}\text { black } \\
\text { shale }\end{array}$ \\
\hline GR (API) & $<95$ & $\begin{array}{l}95- \\
125\end{array}$ & $\begin{array}{c}125- \\
200\end{array}$ & $>200$ & $<80$ & $\begin{array}{l}80- \\
110\end{array}$ & $\begin{array}{c}110- \\
140\end{array}$ & $\begin{array}{c}> \\
200\end{array}$ & $<100$ & $\begin{array}{c}110- \\
150\end{array}$ & $\begin{array}{c}150- \\
200\end{array}$ & $>200$ \\
\hline $\begin{array}{c}\text { DEN } \\
\left(\mathrm{g} / \mathrm{cm}^{3}\right)\end{array}$ & $\begin{array}{c}2.48- \\
2.6\end{array}$ & $\begin{array}{c}2.4- \\
2.6\end{array}$ & $\begin{array}{c}2.2- \\
2.5\end{array}$ & $\begin{array}{c}2.1- \\
2.4\end{array}$ & $\begin{array}{c}2.5- \\
2.6\end{array}$ & $\begin{array}{c}2.45- \\
2.6\end{array}$ & $\begin{array}{l}2.4- \\
2.52\end{array}$ & $\begin{array}{l}2.3- \\
2.43\end{array}$ & $\begin{array}{c}2.5- \\
2.6\end{array}$ & $\begin{array}{c}2.45- \\
2.55\end{array}$ & $\begin{array}{c}2.45- \\
2.55\end{array}$ & $\begin{array}{c}2.33- \\
2.45\end{array}$ \\
\hline
\end{tabular}

Table 5: Model equations for mineral content vs depth in Chang 7

\begin{tabular}{lc}
\hline \multicolumn{1}{c}{ Model equation } & correlation coefficient \\
\hline$\omega_{\text {quartz }}=156.363+0.587 \times \log (\mathrm{RT})-0.201 \times \mathrm{GR} \times 38.994 \times \mathrm{AC}$ & 0.72 \\
$\omega_{\text {feldspar }}=88.765+0.088 \times \log (\mathrm{RT})-0.379 \times \mathrm{CNL}-27.004 \times \mathrm{DEN}$ & 0.64 \\
$\omega_{\text {chlorite }}=-32.514+0.958 \times \mathrm{CNL}+0.02 \times \log (\mathrm{RT})+19.205 \times \mathrm{DEN}-0.04 \times \mathrm{GR} \times 0.102 \times \mathrm{AC}$ & 0.65 \\
$\omega_{\text {illite }}=-574.448-3.363 \times \mathrm{CNL}-0.391 \times \log (\mathrm{RT})+165.95 \times \mathrm{DEN}+0.232 \times \mathrm{GR}+0.916 \times \mathrm{AC}$ & 0.73 \\
$\omega_{\text {calcite }}=-3.76-0.024 \times \mathrm{CNL}+1.797 \times \log (\mathrm{RT})-0.04 \times \mathrm{GR}-1.942 \times \mathrm{DEN}$ & 0.74 \\
$\omega_{\text {dolomite }}=-162.176+55.698 \times \mathrm{DEN}-0.013 \times \mathrm{GR}+0.1 \times \mathrm{AC}$ & 0.59 \\
$\omega_{\text {TOC }}=56.44-0.049 \times \mathrm{AC}-17.05 \times \mathrm{DEN}+0.037 \times \mathrm{GR}$ & 0.98 \\
$\omega_{\text {pyrite }}=-889.29+8.993 \times \mathrm{CNL}-0.369 \times \log (\mathrm{RT})-271.551 \times \mathrm{DEN}-0.445 \times \mathrm{GR}-1.111 \times \mathrm{AC}$ & 0.96 \\
\hline
\end{tabular}
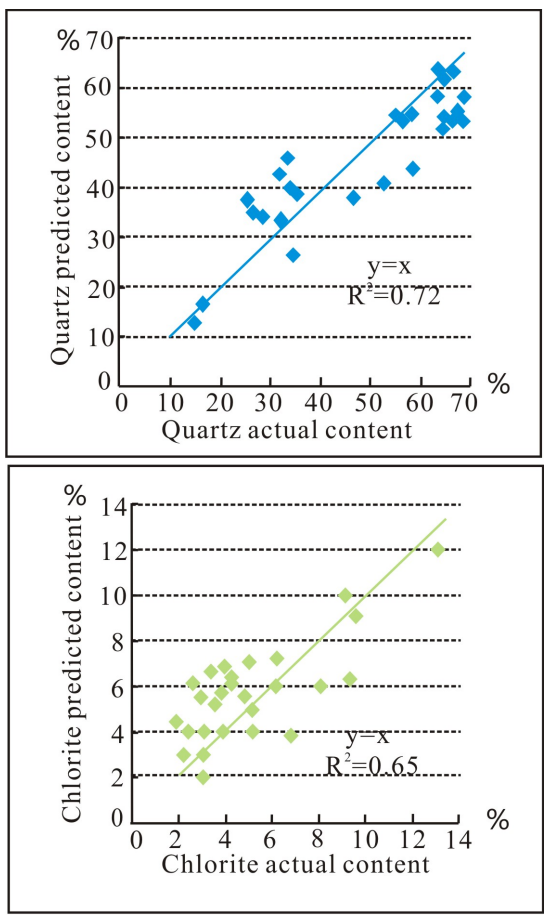
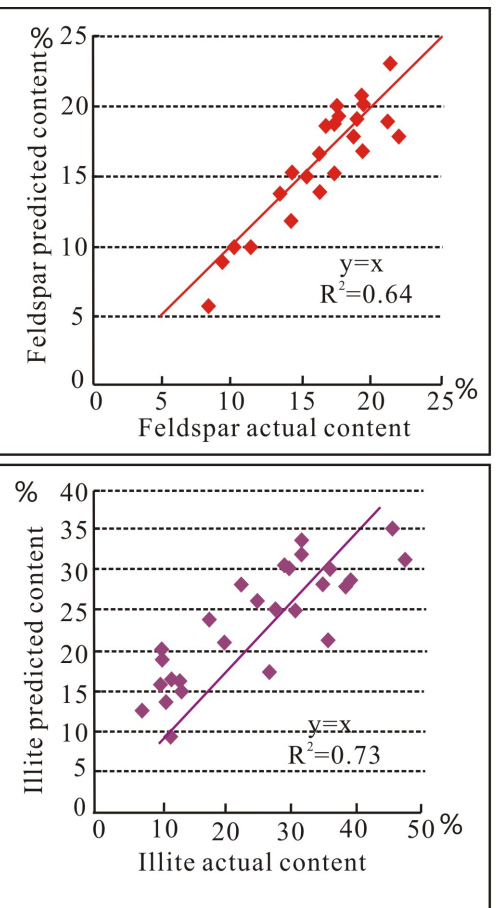

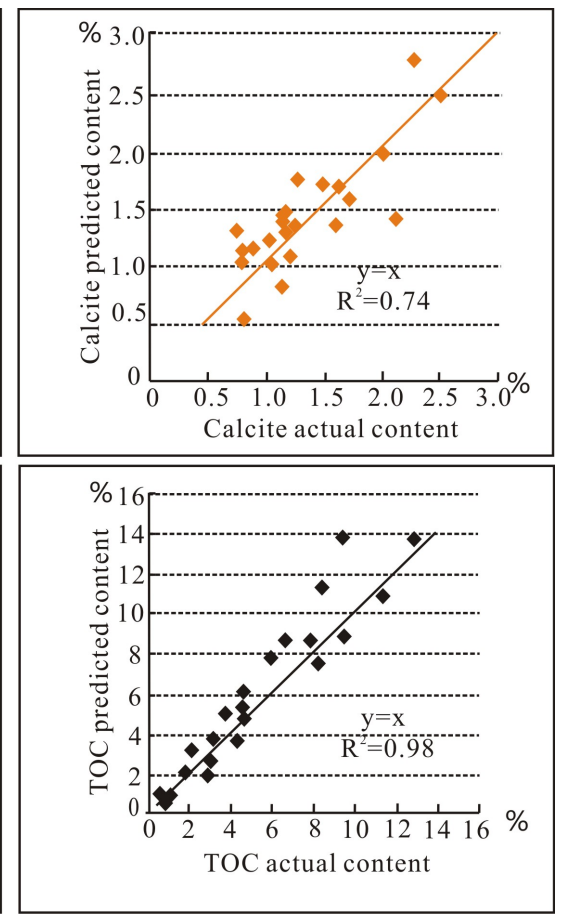

Figure 4: Predicted vs measured mineral content in Chang 7. 
Table 6: Fine-grained sedimentary rocks in Chang 7

\begin{tabular}{|c|c|c|c|c|c|c|}
\hline Rock types & Color & $\begin{array}{l}\text { Single - layer } \\
\text { thickness }\end{array}$ & Structure & Rock types & Mineral content & Distribution \\
\hline \multirow[t]{4}{*}{ Siltstone } & $\begin{array}{l}\text { light } \\
\text { grayish } \\
\text { green, gray }\end{array}$ & $\begin{array}{l}\text { medium- } \\
\text { thin-bedded, } \\
\text { massive }\end{array}$ & $\begin{array}{l}\text { ripple bedding, } \\
\text { horizontal bedding, } \\
\text { deformation } \\
\text { bedding, graded } \\
\text { bedding }\end{array}$ & $\begin{array}{l}\text { lithic feldspar } \\
\text { siltstone }\end{array}$ & $\begin{array}{c}\omega_{\text {feldspar }}>50 \% ; 25 \%< \\
\omega_{\text {debris }}<50 \% ; \omega_{\text {quartz }}<25 \%\end{array}$ & Good \\
\hline & $\begin{array}{l}\text { light } \\
\text { grayish } \\
\text { green, gray }\end{array}$ & $\begin{array}{l}\text { medium- thin - } \\
\text { bedded, massive }\end{array}$ & $\begin{array}{l}\text { ripple bedding, } \\
\text { horizontal bedding, } \\
\text { deformed bedding }\end{array}$ & $\begin{array}{l}\text { feldspathic debris } \\
\text { siltstone }\end{array}$ & $\begin{array}{c}\omega_{\text {debris }}>50 \% ; 25 \%< \\
\omega_{\text {feldspar }}<50 \% ; \omega_{\text {quartz }}<25 \%\end{array}$ & Good \\
\hline & $\begin{array}{l}\text { dark gray, } \\
\text { gray black }\end{array}$ & thin - thick-bedded & graded bedding & feldspar siltstone & $\begin{array}{c}\omega_{\text {feldspar }}>75 \% ; \omega_{\text {debris }}<25 \% ; \\
\omega_{\text {quartz }}<25 \%\end{array}$ & High \\
\hline & $\begin{array}{l}\text { dark gray, } \\
\text { gray black }\end{array}$ & thin - thick-bedded & graded bedding & $\begin{array}{c}\text { feldspar lithic quartz } \\
\text { siltstone }\end{array}$ & $\begin{array}{c}50 \%<\omega_{\text {quartz }}<75 \% ; \omega_{\text {debris }}< \\
25 \% ; \omega_{\text {feldspar }}<25 \%\end{array}$ & High \\
\hline \multirow[t]{2}{*}{ light mudstone } & $\begin{array}{c}\text { gray, gray } \\
\text { green }\end{array}$ & massive & horizontal bedding & $\begin{array}{l}\text { organic-poor illite } \\
\text { mudstone }\end{array}$ & $\begin{array}{c}\omega_{\text {illite }}>75 \% ; \omega_{\text {chlorite }}<25 \% \\
\text { TOC }<2 \%\end{array}$ & Moderate \\
\hline & $\begin{array}{l}\text { gray, gray } \\
\text { green }\end{array}$ & massive & horizontal bedding & $\begin{array}{l}\text { organic-poor chlorite } \\
\text { mudstone }\end{array}$ & $\begin{array}{c}\omega_{\text {chlorite }}>75 \% ; \omega_{\text {illite }}<25 \% \\
\text { TOC }<2 \%\end{array}$ & Moderate \\
\hline \multirow[t]{2}{*}{ dark mudstone } & $\begin{array}{l}\text { dark gray, } \\
\text { gray black }\end{array}$ & thin - thick-bedded & $\begin{array}{l}\text { horizontal bedding, } \\
\text { graded bedding }\end{array}$ & $\begin{array}{l}\text { organic-rich illite } \\
\text { mudstone }\end{array}$ & $\begin{array}{c}\omega_{\text {illite }}>75 \% ; \omega_{\text {chlorite }}<25 \% \\
2 \%<\text { TOC }<4 \%\end{array}$ & High \\
\hline & $\begin{array}{l}\text { dark gray, } \\
\text { gray black }\end{array}$ & thin - thick-bedded & $\begin{array}{l}\text { horizontal bedding, } \\
\text { graded bedding }\end{array}$ & $\begin{array}{l}\text { organic-rich } \\
\text { chlorite mudstone }\end{array}$ & $\begin{array}{c}\omega_{\text {chlorite }}>75 \% ; \omega_{\text {illite }}< \\
25 \% ; 2 \%<\text { TOC }<4 \%\end{array}$ & High \\
\hline \multirow[t]{2}{*}{ black shale } & $\begin{array}{l}\text { gray black, } \\
\text { black }\end{array}$ & thick - bedded & $\begin{array}{c}\text { microlaminae, } \\
\text { straightlaminae, } \\
\text { intermit- } \\
\text { tentlaminae }\end{array}$ & $\begin{array}{l}\text { organic - rich illite } \\
\text { shale }\end{array}$ & $\begin{array}{c}\omega_{\text {illite }}>75 \% ; \omega_{\text {chlorite }}<25 \% \\
\text { TOC }>4 \%\end{array}$ & Moderate \\
\hline & $\begin{array}{l}\text { gray black, } \\
\text { black }\end{array}$ & thick - bedded & $\begin{array}{c}\text { microlaminae, } \\
\text { straightlaminae, } \\
\text { intermit- } \\
\text { tentlaminae }\end{array}$ & $\begin{array}{l}\text { organic-rich } \\
\text { chlorite shale }\end{array}$ & $\begin{array}{c}\omega_{\text {chlorite }}>75 \% ; \omega_{\text {illite }}<25 \% \\
\text { TOC }>4 \%\end{array}$ & Moderate \\
\hline limestone & $\begin{array}{l}\text { dust color, } \\
\text { gray }\end{array}$ & lenticular & - & limestone & $\omega_{\text {calcite }}>75 \% ; \omega_{\text {dolomite }}<25 \%$ & $\begin{array}{l}\text { Less } \\
\text { better }\end{array}$ \\
\hline
\end{tabular}

\section{Vertical distribution characteristics of fine-grained sedimentary rocks}

The $\mathrm{C} 96$ well is in the center of the lake basin. The sedimentary facies are semi - deep - to - deep lacustrine and channel - type gravity flow deposits. We apply the proposed identification method to the entire oil - bearing Chang 7 Section $(118 \mathrm{~m})$ in well C96. The identification results shown in Figure 5 suggest that the oil - bearing Chang 7 Section in the C96 well comprises six main types of fine - grained rock, including mud - debris feldspar lithic quartz fine - grained sandstone, massive feldspar lithic quartz fine sandstone, graded bedded feldspar lithic quartz siltstone, black organic - and illite-rich mudstone, dark organic - and illite-rich shale and banded tuff. The Chang $7_{3}$ layer contains dark organic - and illite - rich shale and graded bedded feldspar lithic quartz siltstone that make up $44 \%$ and $43 \%$ of the total thickness of the layer and locally change into mud - debris feldspar lithic quartz fine - grained sandstone. Chang $7_{2}$ contains massive feldspar lithic quartz fine sandstone, graded bedded feldspar lithic quartz siltstone, and dark organic - and illite 


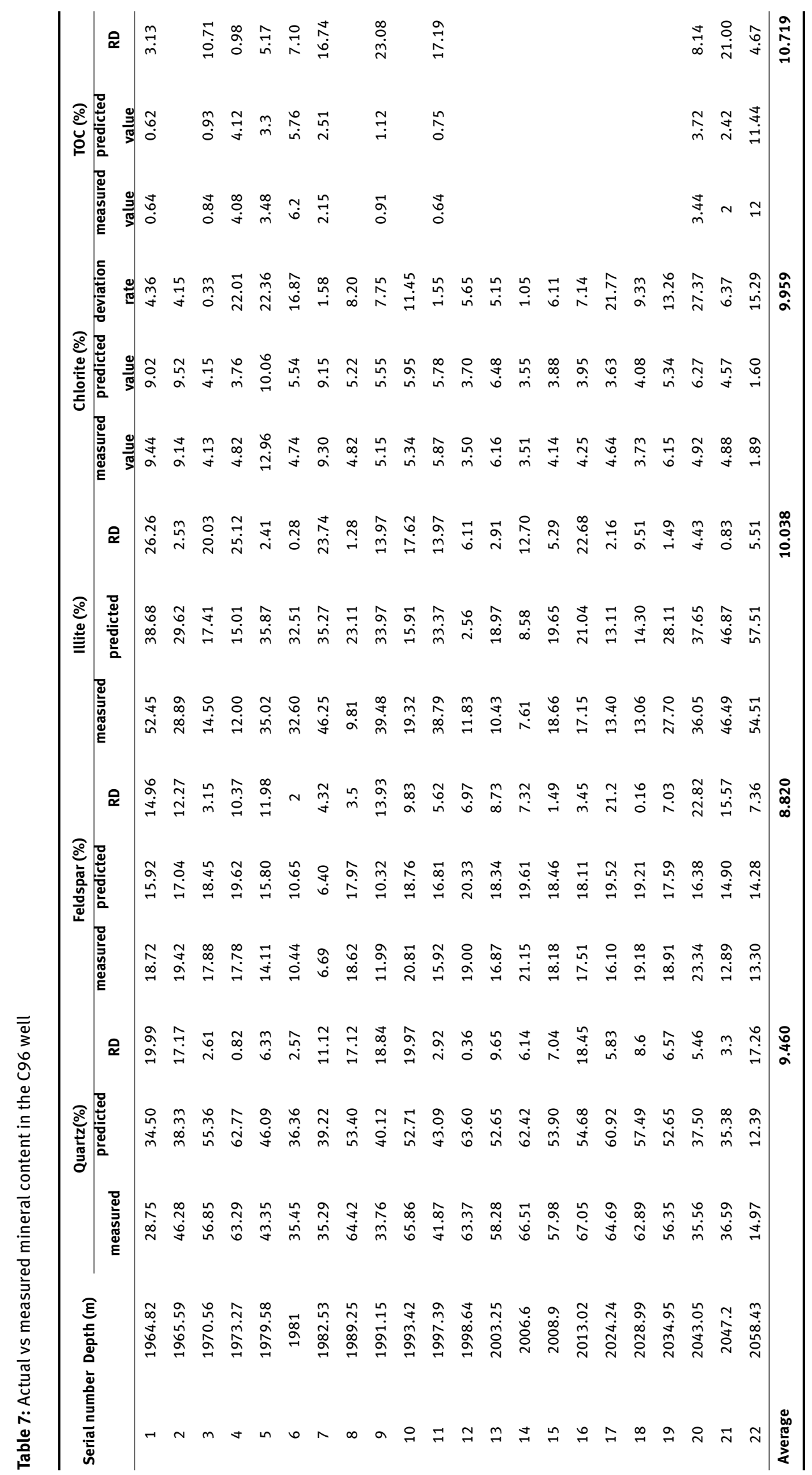




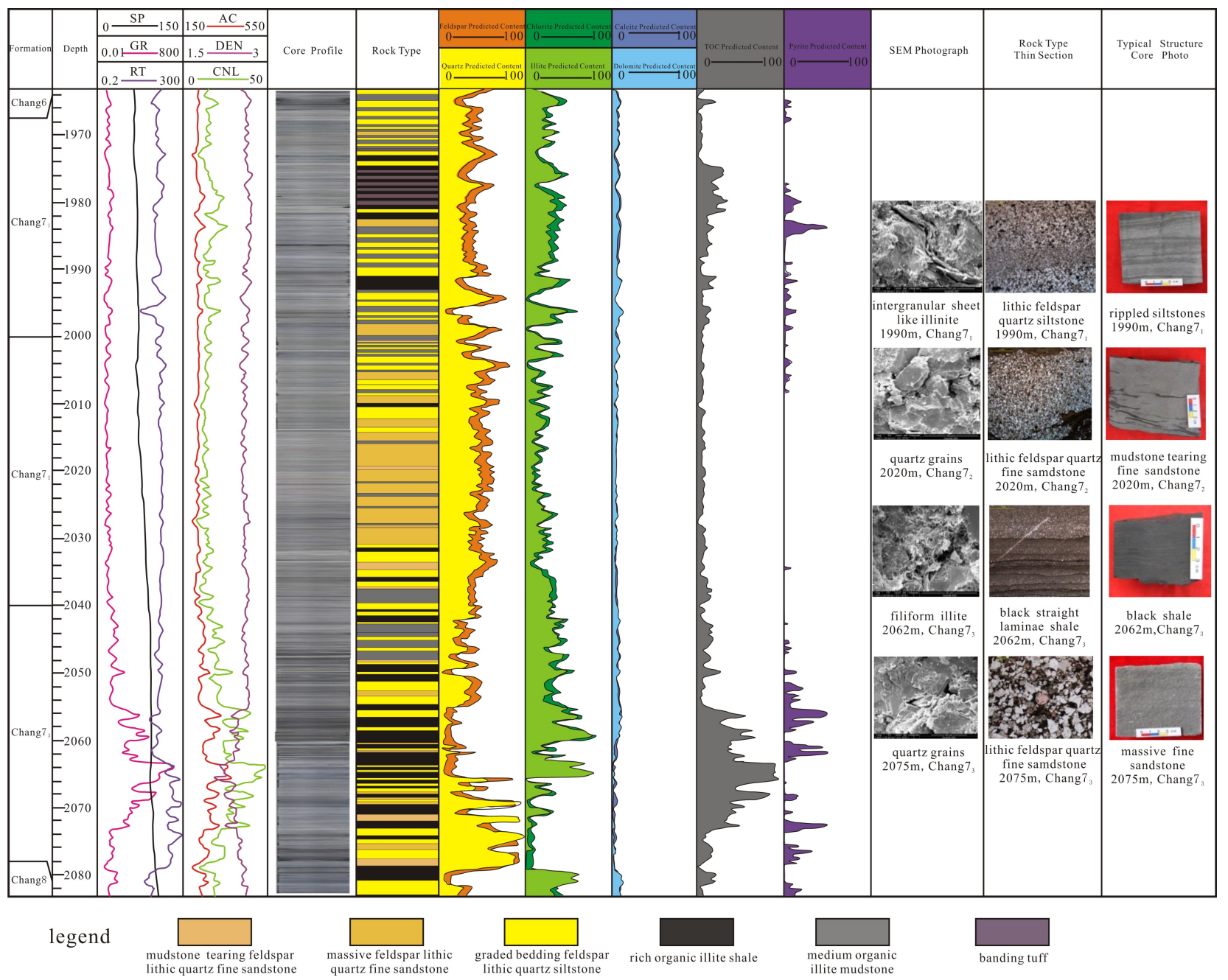

Figure 5: Histogram of the mineral content of the C96 well in Chang 7.

- rich mudstone that account for $47 \%, 24 \%$, and $13 \%$ of the total thickness of the layer and locally contain interbedded thin layers of organic - rich illite shale. Chang $7_{1}$ contains dark organic - and illite - rich mudstone, graded bedded feldspar lithic quartz siltstone, and black organic - and illite - rich shale that account for $29 \%, 25 \%$, and $21 \%$ of the total thickness of Chang $7_{1}$ (Table 8 ).

\section{Conclusions}

Logging curve intersection and multivariate linear regression analysis are commonly used in logging lithologic identification. In this paper, the main fine - grained sedimentary rocks in the study area are preliminarily calibrated by using DEN and GR logging curves crossplot. Then the SPSS software is used to analyze the logging value and the measured mineral content by multiple lin- ear regression analysis, the prediction model of organic carbon and the main mineral content is fitted. Based on the results, a comprehensive designation was made using the rock color, single - layer thickness, texture and structure, mineral composition, and organic matter content of the rock, i.e., "color + single-layer thickness + structure + (organic matter content) mineral composition.” The proposed method can be used for the quantitative analysis of main minerals of fine-grained sedimentary rocks; the method also improves the accuracy and universality of the identification of fine - grained sedimentary rocks using conventional logging data. The proposed methodology yields reliable results and may have wider applicability to fine - grained sedimentary rocks globally.

Acknowledgement: We are grateful to the anonymous reviewers for constructive comments as well as the editors. This research was financially supported by the Sci- 
Table 8: Rock types in the C96 well

\begin{tabular}{lcccccc}
\hline Formation & $\begin{array}{c}\text { Mud - debris feldspar } \\
\text { lithic quartz fine } \\
\text { sandstone }\end{array}$ & $\begin{array}{c}\text { Massive } \\
\text { feldspar lithic } \\
\text { quartz fine - } \\
\text { grained } \\
\text { sandstone }\end{array}$ & $\begin{array}{c}\text { Graded } \\
\text { bedded } \\
\text { feldspar lithic } \\
\text { quartz } \\
\text { siltstone }\end{array}$ & $\begin{array}{c}\text { Organic- and } \\
\text { illite - rich } \\
\text { mudstone }\end{array}$ & $\begin{array}{c}\text { Organic- } \\
\text { and illite - } \\
\text { rich shale }\end{array}$ & $\begin{array}{c}\text { Banded } \\
\text { tuff }\end{array}$ \\
\hline Chang 7 & $10 \%$ & $9 \%$ & $21 \%$ & $29 \%$ & $25 \%$ & $6 \%$ \\
Chang 7 & $7 \%$ & $47 \%$ & $24 \%$ & $13 \%$ & $9 \%$ & $0 \%$ \\
Chang 7 & $2 \%$ & $11 \%$ & $43 \%$ & $0 \%$ & $44 \%$ & $0 \%$ \\
Chang 7 & $6 \%$ & $23 \%$ & $29 \%$ & $14 \%$ & $26 \%$ & $2 \%$ \\
\hline
\end{tabular}

ence and Technology Research Project of Hubei Provincial Department of Education of China (No. Q20181308), the National Natural Science Foundation of China (No. 41672099), and the National Key Basic Research Program of China "973" (No. 2014CB239003).

\section{References}

[1] Curtis J.B., Fractured shale-gas systems. AAPG Bulletin, 2002, 86(11): 1921-1938.

[2] Sageman B.B., Murphy A.E., Werne J.P., Straeten C.A.V., Hollander D.J., Lyons T.W., A tale of shales: the relative roles of production, decomposition, and dilution in the accumulation of organic-rich strata, Middle-Upper Devonian, Appalachian basin. Chemical Geology, 2003,195(1): 229-273.

[3] Bowker K.A., Barnett Shale gas production, Fort Worth Basin: issues and discussion. AAPG Bulletin, 2007, 91(4) : 523-533.

[4] Yang Z.H., Li Z.M., Wang G.S., Teng G.E., Shen B.J., Enlightenment from petrology character, depositional environment and depositional model of typical shale gas reservoirs in North America. Geological Science and Technology Information, 2010, 29(6): 59-65 (in Chinese with English abstract).

[5] Zhang L.Y., Li J.Y., Li Z., Zhang J.G., Zhu R.F., Bao Y.S., Advances in shale oil/gas research in North America and considerations on exploration for continental shale oil/gas in China. Advances in Earth Science, 2014, 29(6): 700-711 (in Chinese with English abstract).

[6] Zhao J.L., Zhang J.F., Xu H., Yu T.X., Zhao D., Geng Y.G., Comparison of geological characteristics and types of typical tight oil in North America. Natural Gas Geoscience, 2015, 27(1): 44-50(in Chinese with English abstract).

[7] Xie Z.K., Research on the Quaternary fine-fraction lithofacies and sedimentation model in Tainan Area, Qaidam Basin. Earth Science Frontiers, 2009, 16(5): 245-250(in Chinese with English abstract).

[8] Liang C., Jiang Z.X., Yang Y.T., Wei X.J., Characteristics of shale lithofacies and reservoir space of the Wufeng-Longmaxi Formation, Sichuan Basin. Petroleum Exploration and Development, 2012, 39(6): 691-698 (in Chinese with English abstract).

[9] Wang Z.F., Zhang Y.F., Liang X.L., Chen F., Jin Q.H., Liu W., Zhang H.B., Li H.P., Characteristics of shale lithofacies formed under different hydrodynamic conditions in the Wufeng-Longmaxi For- mation, Sichuan Basin. Acta Petrolei Sinica, 2014, 35(4): 623632 (in Chinese with English abstract).

[10] Zhang S., Chen S.Y., Tan M.Y., Zhang Y.Y., Sun B.B., Gong W.L., Hu Z.Y., Hou Z.S., Characterization of sedimentary microfacies of shale in the lower third sub-member of Shahejie Formation, western Dongying sag. Acta Petrolei Sinica, 2014, 35(4): 633645 (in Chinese with English abstract).

[11] Liu B., Lü Y.F., Meng Y.L., Li X.N. Guo X.B., Ma Q., Zhao W.C., Petrologic characteristics and genetic model of lacustrine lamellar fine-grained rock and its significance for shale oil exploration: A case study of Permian Lucaogou Formation in Malang sag, Santanghu Basin, NW China. Petroleum Exploration and Development, 2015, 42(5): 598-607 (in Chinese with English abstract).

[12] Zhao X.S., Guo F., Shi L.H., Dang H.L., Lacustrine Fine Grain Deposition and Its Significance to Shale Gas--A Case Study of Chang 7 Reservoir in Yanchang Formation, Liuluoyu Block, Xiasiwan Area. 2015, 2(5): 1-6(in Chinese with English abstract).

[13] Pu X.G., Han W.Z., Zhou L.H., Chen S.Y., Zhang W., Shi Z.N., Yang F., Liu S., Lithologic characteristics and geological implication of fine-grained sedimentation in Ek2 high stand system tract of Cangdong Sag, Huanghua Depression. China Petroleum Exploration, 2015, 20(5): 30-40 (in Chinese with English abstract).

[14] Yuan X.J., Lin S.H., Liu Q., Yao J.L., Wang L., Guo H., Deng X.Q., Cheng D.W., Lacustrine fine-grained sedimentary features and organic-rich shale distribution pattern: A case study of Chang 7 Member of Triassic Yanchang Formation in Ordos Basin, NW China. Petroleum Exploration and Development, 2015, 42(1): 3443 (in Chinese with English abstract).

[15] Chen B.T., Pan S.X., Wang T.Q., Zhang Q.S., Liang S.J. Liu C.Y., Sedimentary microfacies of deepwater fine-grained depositional system and its significance for shale oil and gas exploration in Qingshankou Formation, Qijia-Gulong depression, Songliao Basin, Northeast China. Journal of Central South University (Science and Technology), 2015, 46(9): 3338-3345 (in Chinese with English abstract).

[16] Wu J., Jiang Z.X., Pan Y.W., Zhang Q., He L.Q., Lacustrine finegrained depositional model: a case study of the upper submember of the fourth Member of Paleogene Shahejie Formation in Dongying sag. Acta Petrolei Sinica, 2016, 37(9): 1080-1089 (in Chinese with English abstract).

[17] Zhang S.M., Cao Y.C., Zhu R.K., Wang W., Tu J.Q., Mao Z.G. Bai B., The lithofacies and depositional environment of fine-grained sedimentary rocks of Xiaohu Subsag in Yabulai Basin. Natural Gas Geoscience, 2016, 27(2): 309-319 (in Chinese with English 
abstract).

[18] Wang Y.M., Dong D.Z., Yang Hua, He L., Wang S.Q., Huang J.L., Pu B.L., Wang S.F., Quantitative characterization of reservoir space in the Lower Silurian Longmaxi Shale, southern Sichuan, China. Science China: Earth Sciences, 2014, 44(6): 1348-1356 (in Chinese with English abstract).

[19] Xu Z.X., Heterogeneity of shale reservoirs based on CT images. Lithologic Reservoirs, 2014, 26(6): 46-49 (in Chinese with English abstract).

[20] Yang W., Chen G.J., Hu S.J., Lü C.F., Xu Y., Yang S., Pore characteristics of shale of Lower Paleozoic in southern Sichuan- northern Guizhou. Lithologic Reservoirs, 2015, 27(4): 47-52 (in Chinese with English abstract).

[21] Chen S.Y., Zhang S., Wang Y.S., Tan M.Y., Lithofacies types and reservoirs of Paleogene fine-grained sedimentary rocks in Dongying Sag, Bohai Bay Basin. Petroleum Exploration and Development, 2016, 43(2): 198-208(in Chinese with English abstract).

[22] Kong X.X., Jiang Z.X., Han C., Zheng L.Q., Yang Y.P., Liu Y.P., Laminations characteristics and reservoir significance of finegrained carbonate in the lower 3rd member of Shahejie Formation of Shulu sag. Petroleum Geology and Recovery Efficiency, 2016, 23(4): 19-26 (in Chinese with English abstract).

[23] Bai W.H., Wu Y.B., Gao Z.L., Sun S.S., Study on the Mechanism of Oil Shale Minerogenetic Enrichmen in the Arm of Shallow to Half-deep Lake Depositional Environment. Geological Surwey and Research, 2010, 33(3): 207-214 (in Chinese with English abstract).

[24] Huang B.J., Huang H.T., Wu G.X., You J.J., Geochemical characteristics and formation mechanism of Eocene lacustrine organic-rich shales in the Beibuwan Basin. Acta Petrolei Sinica, 2012, 33(1): 25-31 (in Chinese with English abstract).

[25] Wang L.L., Wang Z.Q., Li Q., Zhang R.C., Controlling Factors of Sandbody Distribution on the Fine-grained Sedimentary Area in Lacustrine Fault Basins. Science Technology and Engineering, 2016, 16(10): 17-22 (in Chinese with English abstract).

[26] Pang J.G., Li S., Yang Y.Y., Liu L.J., Zhu J., Chen D., Study progress of origin of fine-grained sedimentary rocks in deep-water area of lacustrine basin: Taking Yangchang Formation in Ordos Basin as an example. Petroleum Geology \& Experiment, 2014, 36(6): 706-711 (in Chinese with English abstract).

[27] Wu K.L., Chen Z.X., Li J., Xu J.Z., Wang K., Wang S.H., Dong X.H., Zhu Z.Y., Peng Y., Jia X.F., Li X.F., Manipulating the Flow of Nanoconfined Water by Temperature Stimulation. Angewandte Chemie International Edition, 2018, 130(28), 8568-8573.
[28] Wu K.L., Chen Z.X., Li J., Li X.F., Xu J.Z., Dong X.H., Wettability effect on nanoconfined water flow. Proceedings of the National Academy of Sciences, 2017, 114(13), 3358-3363.

[29] Wu K.L., Chen Z.X., Li, X. F., Xu J.Z., Li J., Wang K., Wang S.H. Dong X. H., Flow behavior of gas confined in nanoporous shale at high pressure: Real gas effect. Fuel, 2017, 205, 173-183.

[30] Wu K.L., Li X.F., Guo C.H., Wang, C. C., \& Chen, Z.X., A Unified Model for Gas Transfer in Nanopores of Shale-Gas Reservoirs: Coupling Pore Diffusion and Surface Diffusion. SPE Journal, 2016, 21(05), 1583-1611.

[31] Fu G.M., Yan J.Y., Zhang K., Hu H., Luo F., Current status and progress of lithology identification technology. Progress in Geophysics(in Chinese), 2017, 32 (1) : 26-40.

[32] Tian Y., Sun J.M., Wang X., Tian G.D., Identifying reservoir lithology by step-by-step method and Fisher discriminant. Progress in Exploration Geophysics, 2010, 33(2): 126-130 (in Chinese with English abstract).

[33] Zhong Y.H., Li R., Application of principal component analysis and least square support vector machine to lithology identification. Well Logging Technology, 2009, 33(5): 425-429(in Chinese with English abstract).

[34] Yang H., Huang J.Q., Hu X.T., Shi M.Y., Application of BP neural net in lithologic identification of tight sandstone gas reservoirs. Petroleum Geophysics, 2013, 11(1): 39-42(in Chinese with English abstract).

[35] Li Z.G., Wang Z.H., Liu H.J., The comparative study of the lithologic identification based on conventional well logging information. Chinese Journal of Engineering Geophysics, 2015, 12(1): 77-82.

[36] Zhao J., Yang Y., Chen W.Z., Li J.F., New method for well logging lithologic identification based on elemental capture spectroscopy. Progress in Geophysics, 2015, 30(5): 2342-2348(in Chinese with English abstract).

[37] Gong J.S., Yang M.Y., Wang J, Xu C., Application of ECS logging technology in unconventional reservoir evaluation. Reservoir Evaluation and Development, 2014, 4(2): 76-80(in Chinese with English abstract).

[38] Deng X.Q., Fu J.H., Yao J.L., Pang J.L., Sun B., Sedimentary facies of the Middle - Upper Triassic Yanchang Formation in Ordos Basin and breakthrough in petroleum exploration. Journal of Palaeogeography, 2011, 13(4): 443-455 (in Chinese with English abstract).

[39] Krumbein W.C., The dispersion of fine-grained sediments for mechanical analysis. Journal of Sedimentary Research, 1933, 3(3): 121-135.

[40] Picard M.D., Classification of fine-grained sedimentary rocks. Journal of Sedimentary Research, 1971, 41(1): 179-195. 